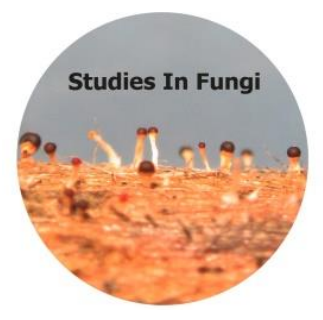

Studies in Fungi 3(1): 256-263 (2018) www.studiesinfungi.org ISSN 2465-4973

Article

Doi 10.5943/sif/3/1/26

Copyright $\odot$ Institute of Animal Science, Chinese Academy of Agricultural Sciences

\title{
Cyathus tenuicorticalis (Agaricales, Basidiomycota), a new species from La Selva Biological Station, Costa Rica
}

\author{
Góis JS', Cruz RHSF ${ }^{2}$, Ovrebo CL $^{3}$ and Baseia IG ${ }^{4}$
}

${ }^{1}$ Curso de Graduação em Ciências Biológicas, Centro de Biociências, Universidade Federal do Rio Grande do Norte, Av. Senador Salgado Filho, 3000, Campus Universitário, Natal, 59072-970, RN, Brazil.

2 Programa de Pós-Graduação em Sistemática e Evolução, Centro de Biociências, Universidade Federal do Rio Grande do Norte, Av. Senador Salgado Filho, 3000, Campus Universitário, Natal, 59072-970, RN, Brazil.

${ }^{3}$ Department of Biology, University of Central Oklahoma, 100 North University Drive, Edmond, OK 73034, United States.

${ }^{4}$ Departamento de Botânica e Zoologia, Centro de Biociências, Universidade Federal do Rio Grande do Norte, Av. Senador Salgado Filho, 3000, Campus Universitário, Natal, 59072-970, RN, Brazil.

Góis JS, Cruz RHSF, Ovrebo CL, Baseia IG 2018 - Cyathus tenuicorticalis (Agaricales, Basidiomycota), a new species for Costa Rica. Studies in Fungi 3(1), 256-263, Doi $10.5943 / \mathrm{sif} / 3 / 1 / 26$

\begin{abstract}
Cyathus tenuicorticalis was found growing on decaying wood from La Selva Biological Station, Costa Rica. Specimens were analyzed using the methodology proposed for the group and specific literature for the genus. The fundamental diagnostic features for this new species are the very thin double-layered cortex in peridioles, exoperidium strongly hirsute, and a platinum bright endoperidium. Description, discussion and photographs of this new species are provided.
\end{abstract}

Key words - Biodiversity - Bird's nest fungi - Gasteriod fungi - Nidulariaceae - Taxonomy

\section{Introduction}

The genus Cyathus Haller consists of organisms with angiocarpic basidiomata in the form of cone, vessel or inverted ball, distinguished by the presence of small internal structures in the fruitbody, which resemble small eggs inside a tiny bird's nest, providing the etymology of the common name "bird's nest fungi" (Brodie 1975). According to Brodie (1975, 1984), Lloyd (1906), most of the species are cosmopolitan, with a few endemic ones.

Few studies have been published on the fungi of Costa Rica, with the earliest records being made by Polakowsky (1877), Bommer \& Rosseau (1896), Stanley (1927), Weston (1933), Garner (1956). For Costa Rica, there are 17 known species of the genus Cyathus: $C$. africanus Brodie, $C$. berkeleyanus (Tul, \& C. Tul.) Lloyd, C. canna Lloyd, C. earlei Lloyd, C. helenae Brodie, $C$. intermedius (Mont.) Tul. \& C. Tul., C. julietae Brodie, C. limbatus Tul. \& C. Tul., C. microsporus Tul. \& C. Tul., C. montagnei Tul. \& C. Tul., C. novae-zeelandie Tul. \& C. Tul., C. olla (Batsch) ex. Pers., C. pallidus Berk. \& C. Curtis, C. poeppigii Tul. \& C. Tul., C. setosus Brodie, C. stercoreus (Schwein.) De Toni, and C. striatus (Huds.) Willd. (Lloyd 1906, Brodie 1975, Calonge et al. 2005). Among the ecological reserves in the country, La Selva Biological Station is one of the most productive in terms of tropical forest research in the world, with several studies on vertebrates, invertebrates and plants (Michener et al. 2009). According to the official list of species for the station, no fungi have been described for La Selva Biological Station (ThreePaths 2018), however, 
some works were published with specific groups of these organisms, demonstrating a huge diversity not yet widely known for the Station (Ovrebio \& Baroni 1988, Welden \& Ovrebo 1989, Miller Jr et al. 1991, Ovrebo 1996, Maas Geesteranus \& Ovrebo 1997, Guzmán \& Ovrebo 2000, Ovrebo \& Baroni 2007, Mata \& Ovrebo 2009). Nevertheless, no Cyathus species was published for this region until now.

There is still a need for further studies on the genus Cyathus, and its wide distribution around the world should be better reported. Due to the lack of specialists, species of the genus are often misidentified, and this directly affects the knowledge of the group's distribution and biodiversity. Thus, the present work aims to increase knowledge about the genus through the description of this new species.

\section{Materials \& Methods}

\section{Fieldwork and morphology}

The specimens were collected in 1986, at La Selva Biological Station and Reserve (Fig. 2a,

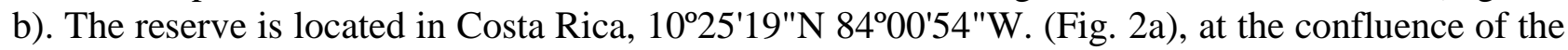
Sarapiquí and Puerto Viejo rivers, in the province of Heredia. It covers an area of 1,600ha of tropical rainforest, with an annual rainfall of $4 \mathrm{~m}^{3}$ and relatively nutrient-rich soil (McDade 1994).

The sample analyzed followed the proposed methodology for Nidulariaceae fungi described by Lloyd (1906), Brodie (1975, 1984), as well as the morphological characteristics proposed by Cruz (2017). The measurements of the basidiomata (height $\times$ width), peridiole size (length $\times$ width), emplacement diameter and texture, cortex type, presence or absence of tunic, size of the tomentum in the exoperidium and the upper border (mouth), and the striae pattern in the exo- and endoperidium were analyzed. To determine the color of the structures, the color chart and color dictionary in the Methuen Handbook of Colour (Kornerup \& Wanscher 1978) was used, through the code composed by the sequence "page + column + line" in the color chart. For the entire macroscopic analysis we used a Nikon SMZ1500 stereomicroscope (Nikon Corporation, Tokyo, Japan).

Microscopically, the size and shape of the basidiospores were analyzed. Microscopic observation was performed using the optical microscope Nikon Eclipse $\mathrm{N} i$-U (Nikon Corporation, Tokyo, Japan). Both stereomicroscope and optical microscope had a Nikon DS-Ril camera attached and the software NIS- Elements AR v.4.51.00 for obtaining and analyzing the images. For the preparation of slides, the peridioles were immersed in water for 48 hours (adapted from Lloyd 1906), and cut free-hand with the aid of a steel sheet. The peridioles were macerated to a fine powder, and a mounting medium composed of $5 \%$ potassium hydroxide $(\mathrm{KOH})$ was added for observation under optical microscopy. The measurements of length and width of 30 basidiospores were obtained, as well as the average length (L), average width (W), the length-width ratio of each spore (Q), and the mean of the ratio (Qm) (Zhao et al. 2008). The spore shape was defined using the Qm value definition proposed by Bas (1969). The identification was carried out using identification keys proposed by specific works (Brodie 1984, Gómez \& Pérez-Silva 1988) and identification keys prepared provisionally based on the original descriptions of materials published soon after 1988, and species that were not covered by the identification keys until 1988 (Stevenson 1975, Stevenson \& Cash 1936, Brodie 1978, Zang 1980, Liu et al. 1984, Liu \& Cao 1987, Gómez \& Pérez-Silva 1988, Liu \& Li 1989, Ren \& Zhou 1992, Mornand 1992, Calonge 1994, Shinners \& Tewari 1998, Chen et al. 2003, Zhou et al. 2004, Zhao et al. 2008, Trierveiler-Pereira \& Baseia 2009, Cruz \& Baseia 2014, Das et al. 2015, Martín et al. 2015, Crous et al. 2016, Silva et al. 2016, Hyde et al. 2016, Crous et al. 2017a, b).

\section{Results}

\section{Taxonomy}


Cyathus tenuicorticalis J. S. Góis, R. Cruz, Baseia \& Ovrebo, sp. nov.

Figs $1-2 \mathrm{c}, \mathrm{d}$

Etymology - In reference to the thin cortical layer of the peridiole.

MycoBank: MB825448

Diagnosis - Peridium infundibuliforme, 7.9 - $10.23 \mathrm{~mm}$ altum, $3.07-6.82 \mathrm{~mm}$ diametrum; exoperidium hirsutus, tomentum plus quam $1 \mathrm{~mm}$ longus, brunneus; endoperidium brunneo cinereo, plicatae, platinum; peridiola $2.04-2.9 \mathrm{~mm} \times 1.69-2.74 \mathrm{~mm}$, badius, circulari vel leniter ellipticis, superficiem lenis vel leniter rugosus, apparent tunica; duplex cortex, tenuissimus; basidiospora leniter ellipticis, $13.7-18.01 \times 9.64-12.75 \mu \mathrm{m}, 1.02-1.76 \mu \mathrm{m}$ murum.

Description - Peridium infundibuliform, $7.9-10.23 \mathrm{~mm}$ in height, $3.07-6.82 \mathrm{~mm}$ in width at the upper part, not expanded at the mouth or tapering abruptly at the base. Emplacement $1.62-3$ $\mathrm{mm}$, conspicuous, tomentose, light brown (7D6). Exoperidium hirsute, dark brown (6F8), with 1.06 - $1.33 \mathrm{~mm}$ tomentum, arranged in regular and flexible tufts. External wall inconspicuously plicated, $0.39-0.70 \mathrm{~mm}$ between the folds. Mouth slightly fimbriated in a continuous pattern, 0.23 - $0.31 \mathrm{~mm}$ in height, dark brown (7E8). Endoperidium brownish grey (6F6), conspicuously plicated, $0.49-0.72 \mathrm{~mm}$ between the folds, bright platinum, contrasting with the exterior. Stipe $1.13-1.66 \mathrm{~mm}$, rusty brown (6E8). Epiphragm not observed. Peridioles $2.04-2.9 \times 1.69-2.74$ $\mathrm{mm}$ in diameter, chestnut brown (6F7), 9 to 13 per basidiomata, circular to slightly elliptical in shape at borders, smooth to slightly rugulose. Tunic present, light brown. Double-layered cortex, very thin, exocortex brown, mesocortex greyish white with compact hyphae, and endocortex dark colored. Basidiospores smooth, hyaline, slightly elliptical to elliptical, apicule absent, $13.7-18.01$ $\times 9.64-12.75 \mu \mathrm{m}(\mathrm{L}=15.40 \mu \mathrm{m} ; \mathrm{W}=10.84 \mu \mathrm{m} ; \mathrm{Qm}=1.42(1.30-1.55)$, with spore wall of $1.02-$ $1.76 \mu \mathrm{m}$.

Habit - Gregarious, on decaying wood.

Material examined - Costa Rica, Province of Heredia, La Selva Biological Station, on decomposed wood, 27 May 1991, leg. Clark L. Ovrebo, CO3196 (Holotype USJ 109098, Isotype UFRN-Fungos 2962); 7 July 1986, leg. Clark L. Ovrebo, CO2131 (Paratype USJ 109097).

Remarks - Cyathus tenuicorticalis is characterized by the strongly hirsute exoperidium with long tomentum (greater than $1 \mathrm{~mm}$ ) (Fig.1a), bright platinum in the endoperidium (Fig. 1b), the very thin cortical layer and circular peridioles (Fig. 1c-d), The spores present a very common size for the genus, with a predominantly ellipsoid shape (Fig. 1e). In addition, this species also presents larger peridioles that can be seen easily in the field (Fig. 2c, d).

According to Brodie's $(1975,1984)$ classification, Cyathus tenuicorticalis could be grouped in the group IV (gracilis), based on the peridium inconspicuously plicated, tomentum aggregated in tufts, tunic thin and elliptical spores, or in the group VII (striatus), based on the exoperidium sometimes inconspicuously plicated, hirsute, tunic present and spores mostly elliptical. However none of these groups presents the complete morphological features, but scattered punctual characteristics, to include $C$. tenuicorticalis correctly in them, a recurring problem in the Brodie's classification due the non-inclusion of species published after 1984.

Morphologically, this species resembles C. bulleri due to hirsute exoperidium, the shape and size of peridioles, and the bright platinum in the endoperidium, but it differs in the larger dimensions of the peridium $(5.59-8 \mathrm{~mm}$ in height, $6-8 \mathrm{~mm}$ in width), greater spacing between external wall plication $(0.4-0.8 \mathrm{~mm})$, single layered cortex, and larger spores $(6.85-11.58 \times 4.98$ $-6.93 \mu \mathrm{m}$ ) (Brodie 1967, Cruz 2017). C. tenuicorticalis can also be compared to C. ellipsoideus due to the hirsute exoperidium, inconspicuous plication in the external wall, presence of tunic, and elliptical spores, but the latter differs in the smaller basidiomata $(6-7 \mathrm{~mm}$ in height, $5-6 \mathrm{~mm}$ in width), shorter tomentum $(0.3-0.6 \mathrm{~mm})$, shorter mouth tomentum $(0.1-0.15 \mathrm{~mm})$, smaller peridioles, exclusively circularshape $(1.53-1.83 \mathrm{~mm} \times 1.25-1.39 \mathrm{~mm})$, and single layered cortex (Brodie 1974). According to the morphological review done by Cruz (2017), the size of the spores present in the original description $(15-16 \mu \mathrm{m} \times 9-10 \mu \mathrm{m})$ is not faithful to the type material analyzed, which presented values of $19.44-23.75 \times 10.59-13.95 \mu \mathrm{m}$, but it still differs from that species. 

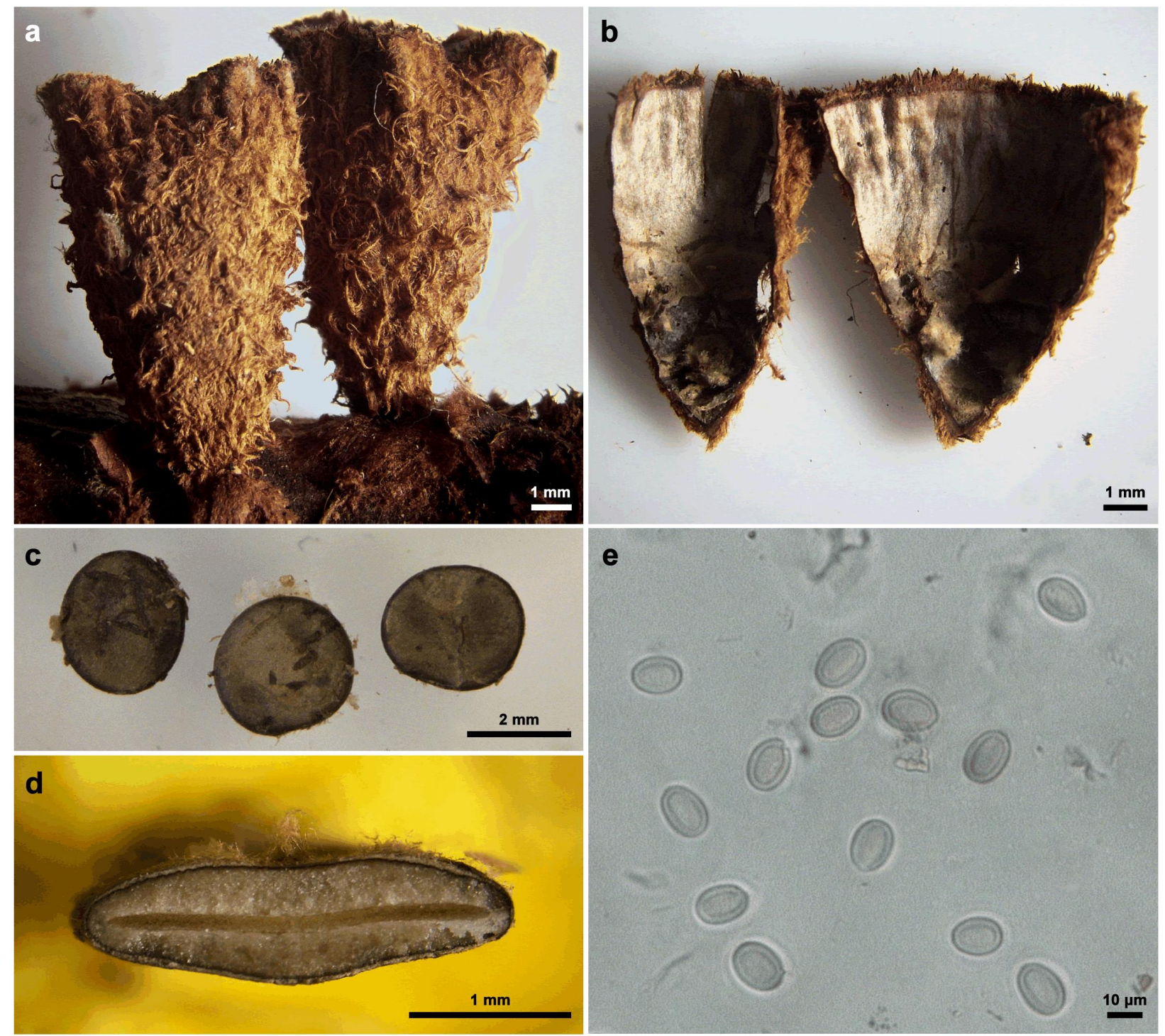

Fig. 1 - Cyathus tenuicorticalis sp. nov. (Holotype USJ 109098): a Exoperidium hirsute, inconspicuously plicated. b Endoperidium showing plications and bright platinum. c Upper view of peridioles with circular shape, showing the smooth surface. $d$ Peridiole double-layered thin cortex. e Basidiospores elliptical-shaped.

Another similar species is $C$. gracilis, showing similarities in the basidiomata size, hirsute exoperidium, tomentum height at the mouth and double layered cortex (Brodie 1973). However, this species differs from $C$. tenuicorticalis by the external smooth wall, smaller tomentum $(0.25-$ $0.6 \mathrm{~mm}$ ), endoperidium smooth to inconspicuously plicated, not bright, and smaller peridioles (1.7 $-1.94 \times 1.65-1.85 \mathrm{~mm}$ in diameter). $C$. tenuicorticalis is also similar to $C$. intermedius due to the presence of hirsute exoperidium, inconspicuously plicated external wall, presence of tunic and tomentum arranged in tufts, but it is differentiated by the smaller dimensions in the basidiomata (4.74 - $5.82 \mathrm{~mm}$ in height, $4.97-6.04 \mathrm{~mm}$ in width), smaller tomentum $(0.32-0.43 \mathrm{~mm})$, endoperidium inconspicuously plicated and single-layered cortex (Tulasne \& Tulasne 1844, Lloyd 1906).

C. tenuicorticalis can be compared with C. striatus and C. berkeleyanus in group VII (striatus) in the classification proposed by Brodie (1975) by the presence of tunic, external wall inconspicuosly plicated and the badiomata size but differs from C. striatus by larger emplacement $(3.46-4.25 \mathrm{~mm})$, smaller peridioles $(1.85-2.28 \times 1.51-1.95 \mathrm{~mm})$ and peridium expanded at the mouth. Due the same characteristics, C. berkeleyanus can be compared to the proposed species but 
differs for the single-layered cortex, smaller basidiospores $(7-13 \mu \mathrm{m} \times 5-8 \mu \mathrm{m})$ and blacker peridioles.
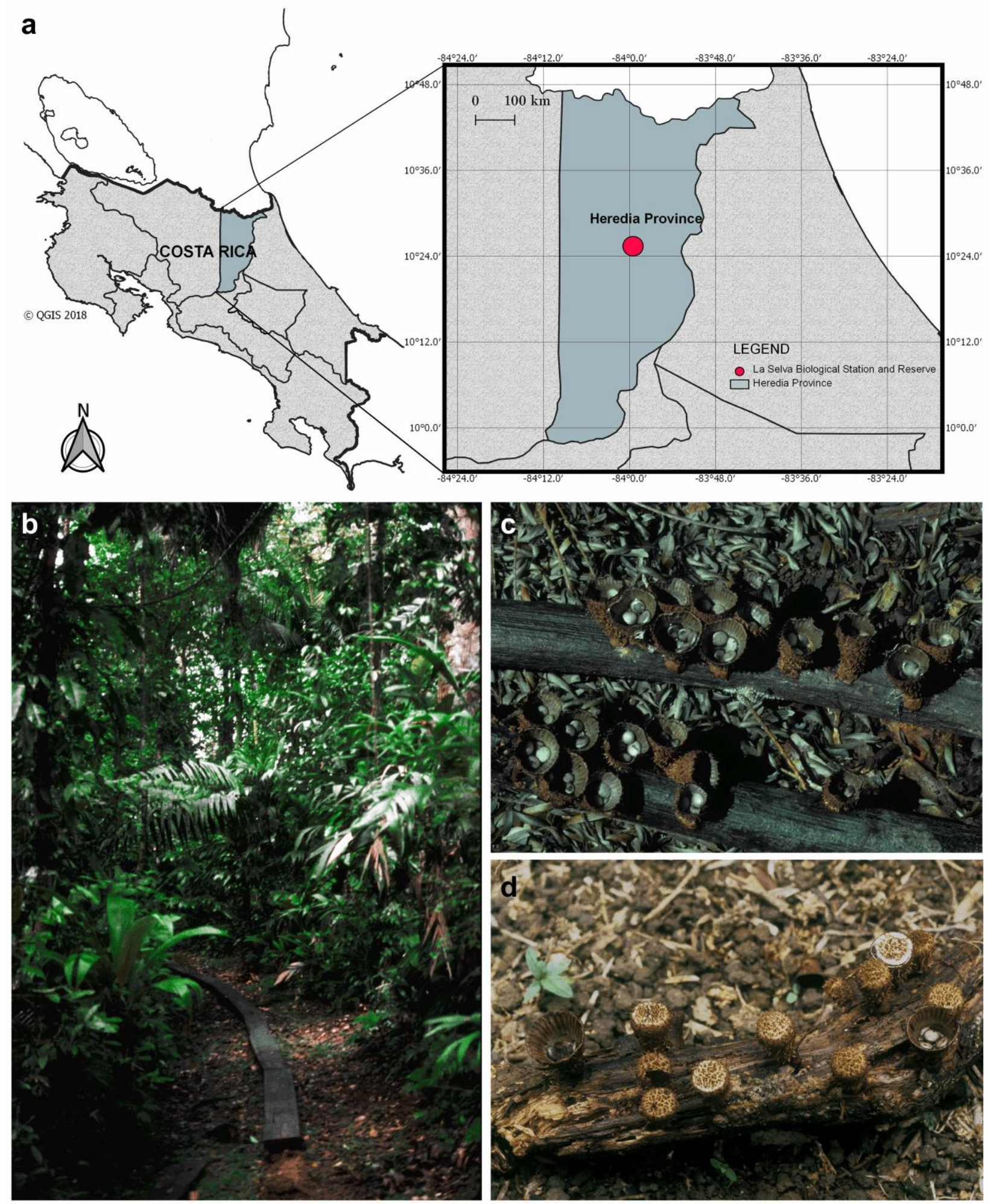

Fig. 2 - a Map showing the collection site, La Selva Biological Station and Reserve - Costa Rica. b Field trail. c Basidiomata in situ (Holotype USJ 109098). d Basidiomata in situ (Paratype USJ 109097).

There are currently 81 Cyathus species known to the world. Many of the new species of the genus are reported using superficial features or characteristics common to other species of Cyathus, 
which makes the use of more concrete and limiting data indispensable to describe a new species, such as details of the cortical layer and surface of the peridioles, as well as DNA extraction to increase the support of the analysis. Some of the recent descriptions already use data such as these (Crous et al. 2016, 2017a, b). However, it was unfortunately not possible to extract DNA from the specimens studied here, and this may be related to the way the exsiccate was dehydrated and preserved. Even so, the macroscopic and microscopic characteristics, when compared with other Cyathus species, allow us to propose Cyathus tenuicorticalis as a distinct and reliable species for science.

\section{Acknowledgements}

C.L. Ovrebo would like to thank the Organization for Tropical Studies for granting permission to collect at La Selva Biological Station. J.S. Góis thank CNPq (Brazilian National Council for Scientific and Technological Development) for the scientific initiation scholarship.

\section{References}

Bas C. 1969 - Morphology and subdivision of Amanita and a monograph on its section Lepidella. Persoonia 5: 285-579.

Bommer JE, Rousseau H. 1896 - Primitiae Florae Costarricensis. Fungi. Bulletin de la Societé Royale de Belgique 35: 151-166.

Brodie HJ. 1967 - Cyathus bulleri, a hitherto undescribed fungus of the Nidulariaceae from the West Indies. Bulletin of the Torrey Botanical Club 94: 68-71.

Brodie HJ. 1973 - A new species of Cyathus from the Philippines. Canadian Journal of Botany 51: 1393-1394.

Brodie HJ. 1974 - A new plicate Cyathus from India. Canadian Journal of Botany 52: 247-249.

Brodie HJ. 1975 - The Bird's Nest Fungi. Canada, University of Toronto Press. 199p.

Brodie HJ. 1978 - A hitherto un-named form of Cyathus olla (Nidulariaceae). Botaniska Notiser 131 (1): 31-34.

Brodie HJ. 1984 - More Bird's Nest Fungi (Nidulariaceae). A supplement to "The Bird's Nest Fungi" (1975). Lejeunia Revue de Botanique, Nouvelle série 112. 70p.

Calonge FD. 1994 - Cyathus stercoreus forma ephedrae, una forma nueva. Boletín de la Sociedad Micológica de Madrid 19: 33-36.

Calonge FD, Mata M, Carranza J. 2005 - Contribución al catálogo de los Gasteromycetes (Basidiomycotina, Fungi) de Costa Rica. Anales del Jardín Botânico de Madrid 62(1): 23-45.

Chen YH, Yu J, Zhou T. 2003 - A new species, a new variety and a new Chinese record of Cyathus. Mycosystema 22: 345-347.

Cruz RHSF. 2017 - Revisão Morfológica e Molecular do Gênero Cyathus Haller (Nidulariaceae, Agaricales, Basidiomycota). Tese de Doutorado, Programa de Pós-Graduação em Sistemática e Evolução. Orientador: Prof. Dr. Iuri Goulart Baseia. Centro de Biociências, Universidade Federal do Rio Grande do Norte, Brasil. 258 p.

Cruz RHSF, Baseia IG. 2014 - Four new Cyathus species (Nidulariaceae, Basidiomycota, Fungi) from the semi-arid region of Brazil. The Journal of the Torrey Botanical Society 141 (2): 173-180.

Crous PW, Wingfield MJ, Burgess TI, Hardy et al. 2016 - Fungal Planet description sheets: 469557. Persoonia. 37:218-403.

Crous PW, Wingfield MJ, Burgess TI, Hardy GEStJ et al. 2017a - Fungal Planet description sheets: 558-624. Persoonia. 38:240-38.

Crous PW, Wingfield MJ, Burgess TI, Carnegie AJ et al. 2017b - Fungal Planet description sheets: 625-715. Persoonia. 39:270-467.

Das K, Hembrom M, Parihar A, Zhao RL. 2015 - A new species of Cyathus (Agaricaceae) from India. 39: 1-7.

Garner JMB. 1956 - Gasteromycetes from Panama and Costa Rica. Mycologia 48: 757-764. 
Gómez CL, Pérez-Silva E. 1988 - Especies de Nidulariales (Gasteromycetes) comunes em Mexico. Revista Mexicana de Micología, 4: 161-183.

Guzmán G, Ovrebo CL. 2000 - New observations on sclerodermataceous fungi. Mycologia 92 (1): 174-179.

Hyde KD, Hongsanan S, Jeewon R, Bhat DJ et al. 2016 - Fungal diversity notes 367-491: taxonomic and phylogenetic contributions to fungal taxa. Fungal Diversity. 80:1-270.

Kornerup A, Wanscher JH. 1978 - Methuen Handbook of Colour, $3^{\text {a }}$ Ed. London: Eyre Methuen. (revised by Don Pavey).

Liu B, Cao JZ. 1987 - A new species of the genus Cyathus. Acta Mycologica Sinica 1 (Suppl.): 316-317.

Liu B, Li YM. 1989 - New species, new variety and new record of the genus Cyathus from China. Acta Mycologica Sinica 8 (4): 289-295.

Liu B, Shangguan TI, Yuan PG. 1984 - A new species of the genus Cyathus. Acta Mycologica Sinica 3: 196-198.

Lloyd CG. 1906 - Nidulariaceae. Mycological Writings. Cincinnati, Ohio. 32p.

Martín MP, Cruz RHSF, Dueñas M, Baseia I, Telleria MT. 2015 - Cyathus lignilantanae sp. nov., a new species of bird's nest fungi (Basidiomycota) from Cape Verde Archipelago. Phytotaxa 236 (2): 161-172.

Maas Geesteranus RA, Ovrebo CL. 1997 - A new species and new section of Mycena from Costa Rica. Persoonia 16 (3): 393-395.

Mata JL, Ovrebo CL. 2009 - New reports and illustrations of Gymnopus for Costa Rica and Panama. Fungal Diversity 38: 125-131.

Michener W, Bildstein K, McKee A, Parmenter R et al. 2009 - Biological field stations: research legacies and sites for serendipity. BioScience, 300-310.

Miller Jr OK, Ovrebo CL, Burk WR. 1991 - Neolysurus: a new genus in the Clathraceae from Costa Rica. Mycol. Res. 95 (10): 1230-1234.

Mornand J. 1992 - Sur une forme de Cyathus stercoreus forma halepensis fo. nov. Documents Mycologiques mémoire hors série 22 (85): 5-9.

McDade LA. 1994 - La Selva: Ecology and Natural History of a Neotropical Rain Forest. $1^{\text {a }}$ Ed. University of Chicago Press, 486 p.

Ovrebo CL. 1996 - The agaric flora (Agaricales) of La Selva Biological Station, Costa Rica. Rev. Biol. Trop. 44: 39-57.

Ovrebo CL, Baroni TJ. 1988 - Three new species of Rhodocybe from Costa Rica. Mycologia 80 (4): 508-514.

Ovrebo CL, Baroni TJ. 2007 - New taxa of Tricholomataceae and Entolomataceae (Agaricales) from Central America. Fungal Diversity 27 (1): 157-170.

Polakowsky H. 1877 - Beitrag zur kenntnis der Flora von Costa Rica in Central Amerika. Verhandlungen des Botanischen Vereins für die Provinz Brandenburg 19: 58-78.

Ren W, Zhou TX. 1992 - New species and new variety of the genus Cyathus from China. Acta Mycologica Sinica 11 (1): 23-27.

Shinners TC, Tewari JP. 1998 - Morphological and RAPD analyses of Cyathus olla from crop residue. Mycologia 90 (6): 980-989. http://dx.doi.org/10.2307/376127.

Silva MA, Barbosa MMB, Baseia IG, Malosso E. 2016 - Novelties in Cyathus (Basidiomycota): new species and a phylogenetic analysis. Nova Hedwigia. 103(1-2):57-69.

Stanley PG. 1927 - The flora of Barro Colorado Island. Smithsonian Miscellanean Collection 78: 6-7.

Stevenson JA. 1975 - Fungi of Puerto Rico and the Virgin Islands. Contributions of the Reed Herbarium. 23:1-742.

Stevenson JA, Cash EK. 1936 - The new fungus names proposed by C.G. Lloyd. Bulletin of the Lloyd Library 35: 1-209.

ThreePaths 2018 - https://www.threepaths.co.cr/laselva_species_list.shtml (accessed 03 March 2018). 
Trierveiler-Pereira L, Gomez-Silva AC, Baseia IG. 2009 - Notes on gasteroid fungi of the Brazilian Amazon rainforest. Mycotaxon 110: 73-80.

Tulasne LR, Tulasne C. 1844 - Recherches sur l'eorganisation et le mode de frutification des champignons de la tribu des Nidulariées, suivies d'um essai monographique. Annales des Sciences Naturalles series 3 1: 41-107.

Welden AL, Ovrebo CL. 1989 - Notes on tropical and warm temperate Basidiomycetes. Mycotaxon 34 (2): 601-614.

Weston Jr WH. 1933 - The fungi of Barro Colorado Island. Scientific Monthly 36: 387-407.

Zang M. 1980 - Some new species of Basidiomycetes from the Xizang Autonomous Region of China. Acta Microbiologica Sinica 20 (1): 29-34.

Zhao RL, Desjardin DE, Soytong K, Hyde KD. 2008 - A new species of bird's nest fungi: characterization of Cyathus subglobisporus sp. nov. based on morphological and molecular data. Persoonia 21: 71-76.

Zhou TX, Zhao LZ, Zhao RL, Chen YH. 2004 - Bird's Nest Fungi from China. Fungal Diversity 17: $243-251$. 